\title{
DISTRACTED DRIVING: DYING TO TEXT YOU
}

\author{
David M. Douglas, Robert Morris University,douglas@rmu.edu \\ Karen L.Paullet, Robert Morris University, paullet@rmu.edu \\ Jamie L. Pinchot, Robert Morris University, pinchot@rmu.edu
}

\begin{abstract}
Distracted driving, in particular texting while driving, is capturing national attention. Governments, industry and insurance agencies are aware of the growing problem and have enacted laws and promoted guidelines for safer driving habits. As of July 2012, 37 states have enacted texting while driving laws. This study focused on texting as a contributing factor to driver distraction amongst university students. Overall, the findings indicate that both age and gender are statistically significant factors affecting whether students text while driving. From our sample data set, results show that males aged 18 to 33 years old are more likely to text while driving. Awareness and education are critical if we expect to see a reduction in traffic accidents and fatalities attributed to driver distraction.
\end{abstract}

Keywords: Distracted Driving, Texting, Mobile Technology, Mobile Devices, Cell Phones

\section{INTRODUCTION}

Distracted driving has been around since people first sat behind the steering wheel of a car. It is easy to switch on the "auto pilot" as we go about our daily routine tasks. Drivers can become distracted from talking with passengers, changing the radio, eating, drinking, adjusting a mirror or reading a map. Now, more than ever, people are being distracted by their cell phones or other mobile devices while driving. One of the many unintended consequences of mobile communication technology is distracted driving. Distracted driving has become a serious problem in the United States. As we wait at a traffic light watching the passing cars go by we will see dozens of people talking or texting on their mobile phones. Governments, industry, and insurance agencies have become aware of the growing problem and are trying to enact laws and policies for safer driving. As of July 2012, 37 states have laws banning texting while driving [11]. For the purpose of this study, the researchers will focus on talking or texting on a mobile device while driving.

The National Highway Transportation Safety Administration (NHTSA) [11] defines distracted driving as "any activity that could divert a person's attention away from the primary task of driving." Distractions include texting, using a cell phone or smart phone, eating, drinking, talking to passengers, grooming, reading, and adjusting the GPS or radio. Text messaging is the most alarming distraction because it requires simultaneous visual, manual, and cognitive attention from the driver [11]. People sending or receiving a text take their eyes off the road for approximately 4.6 seconds. If a person sends a text while traveling at $55 \mathrm{mph}$, it is equivalent to a person driving the length of a football field blinded [11]. Texting and driving is extremely dangerous. Approximately $16 \%$ of distracted driving crashes involve drivers under the age of 20. It has been estimated that 800,000 drivers are using handheld cell phones at any given moment during daylight hours [11].

Without a doubt, distracted driving is an issue of concern with serious consequences. Mobile device dependency could be feeding into the problem. Are we so addicted to our mobile phones that the benefit of using them outweighs the dangers of talking or texting while driving? This study sought to determine how mobile technology dependency affects distracted driving habits in university students. The following research questions were explored:

RQ1: Is age a factor in whether or not students engage in texting or talking on mobile devices while driving? RQ2: Is gender a factor in whether or not students engage in texting or talking on mobile devices while driving? 


\section{Issues in Information Systems}

Volume 13, Issue 1, pp. 275-283, 2012

\section{LITERATURE REVIEW}

As of December 2011 there were 331.6 million wireless subscribers in the United States who sent approximately 193 billion text messages [3]. As of April 2012, 404,472 automobile crashes involving drivers using cell phones and texting occurred in the United States. This is one crash in approximately every 24 seconds [9].

Just, Keller and Cynkar [7] conducted a study at Carnegie Mellon University regarding brain distraction while driving. The researchers examined MRI pictures of the brain while participants drove and answered true/false questions. The results showed that driving while using a cell phone reduces the amount of brain activity associated with driving by $37 \%$. The U.S. Department of Transportation [11] classifies talking on cell phones, manipulating hand held phones, and text messaging as driver distractions.

In 2011, the Harris Poll conducted a study of 2,163 adults focusing on distracted driving. The study revealed that $60 \%$ of drivers use cell phones while driving even though $91 \%$ of participants believe that it is unsafe to do so [6]. This trend was particularly common among participants between the ages of 18 and 34. Additionally, 1 in 5 drivers send or receive text messages while driving. Once again, participants between the ages of 18 and 34 were more likely to text while driving than other age groups. Research has shown that both handheld and hands-free cell phones are almost equally dangerous to drivers [6]. The study also revealed that $72 \%$ of participants ages $18-34$ and $69 \%$ of participants ages 35-46 are more likely to use cell phones while driving than 59\% of participants ages $47-65$. They are also almost twice as likely to use cell phones while driving as drivers over the age of 65 . Texting while driving is also more common among younger drivers showing that $49 \%$ of drivers with cell phones under the age of 35 send or read text messages while driving. Only $24 \%$ of participants ages $35-46,11 \%$ of those ages $47-65$ and $1 \%$ of participants over the age of 65 send or read text messages while driving [6].

A 2010 study conducted by the Pew Internet \& American Life Project [8] surveyed 2,252 adults on cell phone distractions. Forty-seven percent of texting adults reported they have sent or read a text message while behind the wheel. Seventy-five percent of adults owning cell phones, reported that they have talked on a mobile phone while driving. In addition, $49 \%$ reported that they have been a passenger in a car when the driver was texting on their mobile phone. An alarming 44\% indicated that they have been a passenger in a car when the driver used a cell phone in a way that put themselves or others in danger [8].

Braitman and McCartt [2] conducted a telephone survey of 1,219 drivers in 48 states and the District of Columbia using random samples of landline and cell phones. One of the goals of the study was to obtain information on driver cell phone use including how often drivers text and talk. Forty percent of drivers reported talking on their phones while driving each week. Male drivers, 49\%, and drivers between the ages of 25-29, 69\%, were most likely to report talking while driving. Thirteen percent of drivers reported texting while driving and this percentage was highest, at $43 \%$, among drivers between the ages of 18-24 [2]. Additionally, $12 \%$ of drivers reported texting while driving in states that had laws banning texting while driving compared to $14 \%$ in states that did not have texting laws in place [2].

On September 30, 2009, President Obama signed Executive Order 13513, which prohibited federal employees from engaging in text messaging when driving government owned vehicles, or driving privately owned vehicles on government time or when using electronic equipment supplied by the government [4]. Government contractors, subcontractors, recipients and sub-recipients are to follow the ban in regard to texting as well [4].

A 2010 survey conducted by the U.S. Department of Transportation [10] found that nine of 10 respondents, regardless of age, supported laws that banned texting and driving and six of 10 supported laws that banned cell phone use while driving. Additionally, $86 \%$ of males and $90 \%$ of females felt unsafe when the driver was sending a text message or e-mail and $84 \%$ of males and $88 \%$ of females felt unsafe when the driver was reading a text message or e-mail. Twenty-five percent believed that their driving ability did not change when sending a text or e-mail [10]. 


\section{Issues in Information Systems}

Volume 13, Issue 1, pp. 275-283, 2012

As of April 2012 there were no states or territories that banned the use of all handheld and hands-free cell phones for all drivers. However, 31 states and the District of Columbia prohibited the use of cell phones by novice drivers. Currently, 37 states, the District of Columbia, and Guam ban text messaging for all drivers. The District of Columbia, Guam, and 34 states have primary enforcement of the regulation. Primary enforcement of the law is defined as when a law enforcement officer can issue a citation to the driver for using a handheld mobile device without observing another traffic offense [5].

Driving is a privilege which conveys great responsibility and is subject to many distractions. According to the AAA Foundation for Public Safety, "Distracted driving contributes to up to 8,000 crashes every single day" [1, para. 2]. Passengers (adults, young children, infants) are frequently reported as contributing to distracted driving. Young children are reported to be more than four times as distracting as adults and infants eight more times distracting. Moreover, people who use a cell phone while driving quadruple their risk of crashing [1].

\section{RESEARCH METHODOLOGY}

This exploratory research study examined mobile device dependency and its effects on distracted driving habits of college students at a mid-Atlantic university. Researchers developed a survey instrument as an extension of a previous survey instrument measuring technology dependence [12]. The extended survey included an additional focus on mobile device dependency, usage, and habits related to distracted driving.

A convenience sample was utilized, with 168 responses from both undergraduate and graduate students at the university. The sample had a 5\% margin of error and a 95\% confidence level. The survey instrument that was administered included 31 questions and began by addressing basic demographics of gender, age, and school affiliation within the university. Next, the survey addressed usage habits regarding mobile devices. Participants were asked to indicate the number of phones, both landline and mobile, that they own and use. They were also asked to specify preferred methods of communication, such as talking, texting, or emailing on a mobile device. In addition, the survey addressed level of reliance on mobile devices, including whether students felt that they were addicted to their mobile device, and whether they talk or text on their mobile device while driving.

\section{RESULTS}

\section{Age as a Factor in Talking or Texting While Driving}

Respondents were between the ages of 18 and 53, with an average age of 28 and median age of 25. For the purpose of data analysis, ages were categorized into three groupings based on generational affiliations. The Millennials (ages 18-33) made up the overwhelming majority, 79\%, of the sample. Generation X (ages 34-45) represented 15\% of the sample and the Baby Boomers (ages 46-64) included 6\% of the sample. The number of participants in each age group is shown in Table 1.

Table 1. Participants by Age Group

\begin{tabular}{|l|c|c|}
\hline Age Groups & \# of Participants & Percentage of Sample (n=168) \\
\hline $18-33$ (Millennials) & 132 & $79 \%$ \\
\hline $34-45$ (Generation X) & 35 & $15 \%$ \\
\hline $46-64$ (Baby Boomers) & 11 & $6 \%$ \\
\hline
\end{tabular}

Research question one sought to determine if age was a factor in whether or not students engage in texting or talking on mobile devices while driving. The survey directly asked participants whether they talk on their mobile phones or text on their mobile phones while driving. The questions were worded "Do you talk on your cell phone while driving?" and "Do you text while driving?," respectively, implying that the participant has talked or texted while driving more than once. 


\section{Issues in Information Systems}

Volume 13, Issue 1, pp. 275-283, 2012

Eighty-four percent indicated that they talk on their mobile phone while driving. The ages of respondents within this $84 \%$ who responded in the affirmative were not equally spread out amongst the generations. Within this group, the younger generation of 18-33 year-old Millennials comprised the highest percentage, at $80 \%$. Generation X, including 34-45 year-olds, made up 13\% and the Baby Boomers, aged 46-64 years old, trailed with 7\%. The percentage of students who reported talking on their mobile phone while driving is shown in Figure 1, categorized by age group.

There was very little difference between age groups and a chi-square test indicated that no statistically significant relationship exists between age and talking while driving.

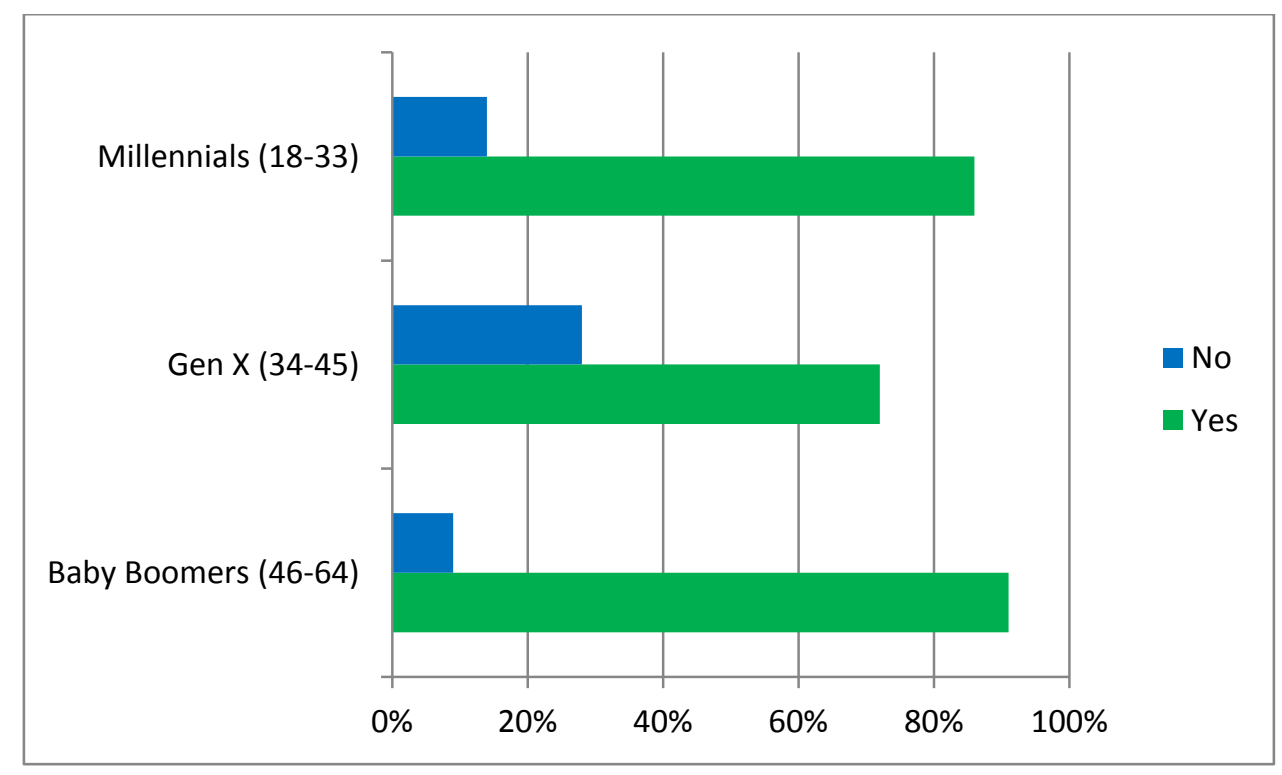

Figure 1. Percentage of Students Who Talk While Driving, By Age

Fifty-one percent of students reported texting while driving. Of those who responded affirmatively, $91 \%$ were in the Millennial age group. Generation X made up 7\% of this group, and the Baby Boomers only 2\%. The percentage of students who reported texting while driving, by age group, is shown in Figure 2.

A strong statistically significant relationship was found between age and texting while driving (chi-square $=15.492$, $d f=2, \mathrm{p}<.000)$. This result indicates that as a student's age decreases, the more likely he or she is to text while driving. In regard to research question one, age does appear to be a factor in regard to student's likelihood of texting while driving, but it is not a factor in regard to talking on a mobile phone while driving. 


\section{Issues in Information Systems}

Volume 13, Issue 1, pp. 275-283, 2012

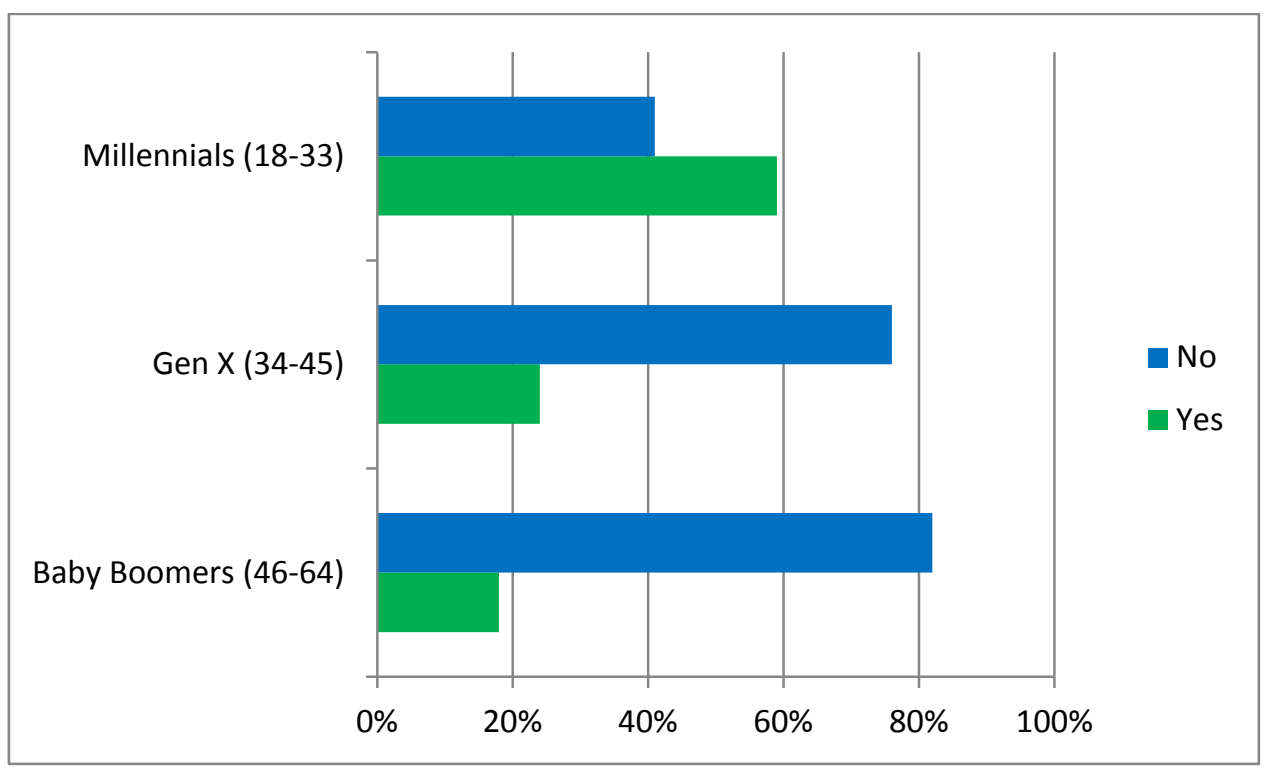

Figure 2. Percentage of Students Who Text While Driving, By Age

\section{Gender as a Factor in Talking or Texting While Driving}

Findings indicated that the majority of respondents in the sample were male, $68 \%$, while $32 \%$ were female. The number of participants representing each gender are shown in Table 2.

Table 2. Participants by Gender

\begin{tabular}{|l|c|c|}
\hline Gender & \# of Participants & Percentage of Sample $(\mathbf{n = 1 6 8})$ \\
\hline Male & 114 & $68 \%$ \\
\hline Female & 54 & $32 \%$ \\
\hline
\end{tabular}

Research question 2 sought to determine if gender was a factor in whether or not students text or talk on mobile devices while driving. Eighty-seven percent of males reported talking on a cell phone while driving compared to $78 \%$ of females, as shown in Figure 3. A chi-square test found no statistically significant relationship between gender and talking behind the wheel. 


\section{Issues in Information Systems}

Volume 13, Issue 1, pp. 275-283, 2012

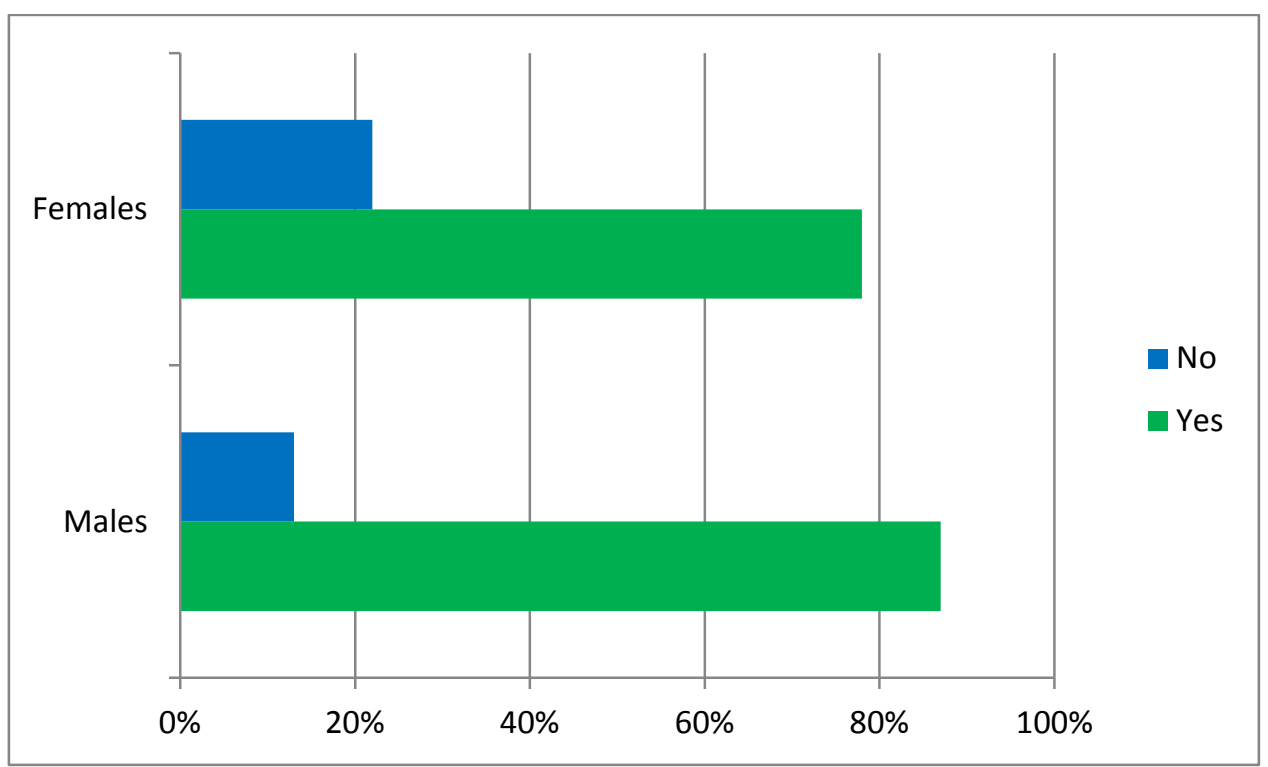

Figure 3. Percentage of Students Who Talk While Driving, By Gender

Approximately $58 \%$ of males reported texting while driving compared to $37 \%$ of females, as shown in Figure 4 . A chi-square test was performed, and a statistically significant relationship was found between gender and texting while driving (chi-square $=6.380, d f=1, \mathrm{p}<.01$ ). This indicates that males, at least within this sample, are more likely to engage in texting while driving.

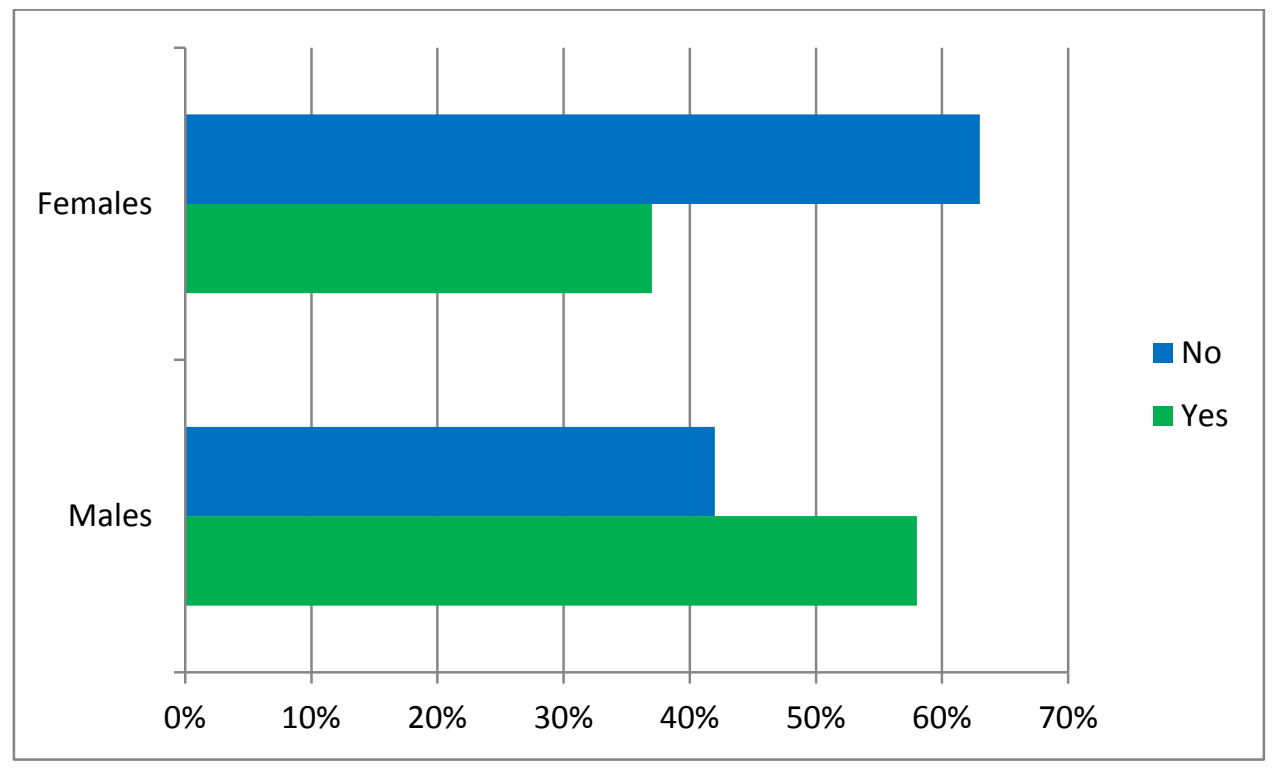

Figure 4. Percentage of Students Who Text While Driving, By Gender

In regard to research question two, gender does affect a student's likelihood of texting while driving, but it is not a factor affecting whether or not a student talks on a mobile phone behind the wheel. 


\section{Issues in Information Systems}

Volume 13, Issue 1, pp. 275-283, 2012

Overall, our findings indicate that both age and gender are statistically significant factors affecting whether students text while driving. From our sample data set, results show that males aged 18 to 33 years old are more likely to text while driving. This result may be indicative of younger students having been early adopters of texting and perhaps more accepting of texting in general. This theory is supported by other findings of our study. Students were asked how they communicate most often, by talking on a landline phone, talking on a cell phone, e-mail, or texting. Younger students in the Millennial age group were more likely to communicate by texting on a mobile phone, as shown in Figure 5. Generation X students were most likely to communicate by e-mail. Baby Boomers also reported that they were most likely to communicate by talking on a mobile phone.

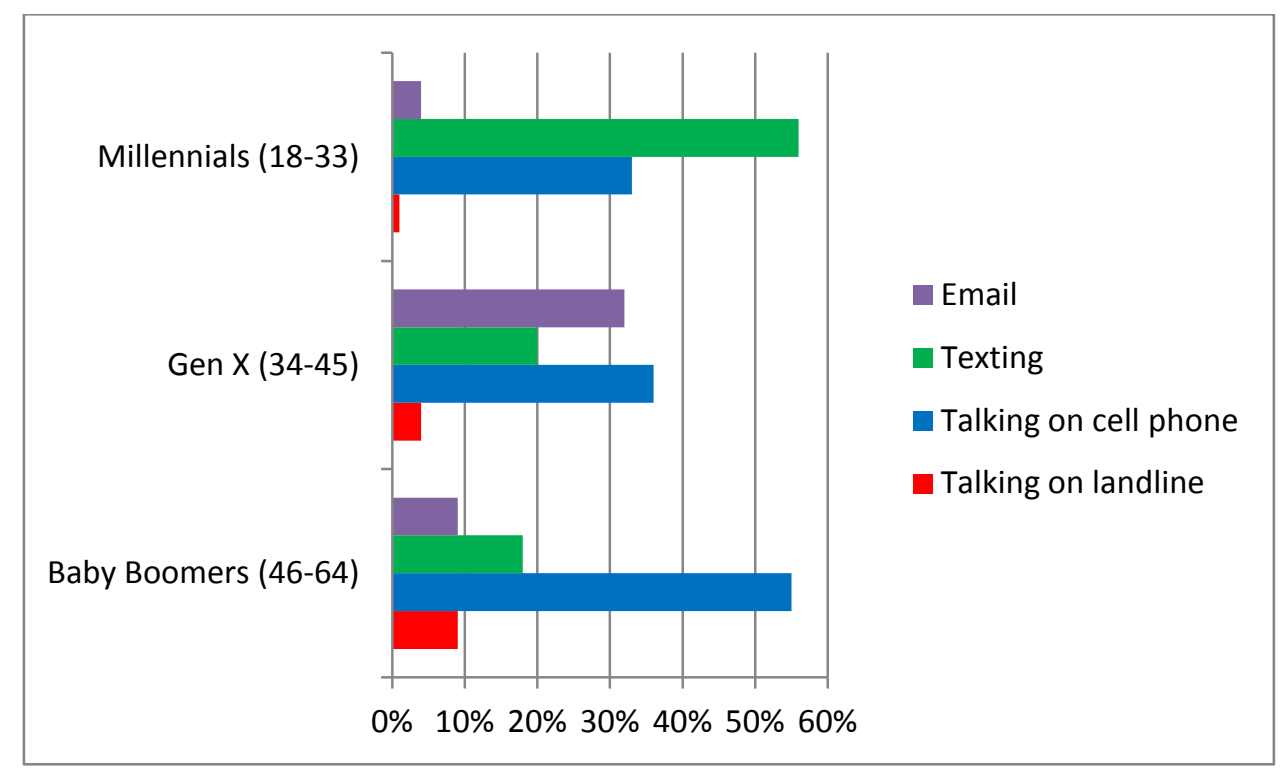

Figure 5. Percentage of Students Who Communicate Most Often by E-mail, Texting, Talking on a Cell Phone, or Talking on a Landline, By Age

A chi-square test indicated a strong statistically significant relationship between age and most frequent communication method (chi-square $=37.451, d f=12, \mathrm{p}<.000$ ). These findings indicate that younger students are more likely to use texting as their preferred communication method.

\section{DISCUSSION}

This study revealed that approximately $58 \%$ of males reported texting while driving. Additionally, the study found that students between the ages of 18-33 are more likely to text while driving than other age groups. As a student's age progresses, they are less likely to report texting while driving. These findings concur with earlier studies reported in the literature review.

Distracted driving is a major unintended consequence of mobile communication technology. In fact, distracted driving has become the latest battle cry for pundits and politicians. Their goal is to create public awareness that cell phones contribute to distracted driving. Although it might be easy to place the blame on generational trends, distracted driving affects everyone. One only has to examine the statistical data to realize that distracted driving is a daunting threat to both the unsuspecting public and the indifferent offender.

On March 8, 2012, Pennsylvania became the thirty-fifth state, plus the District of Columbia, to enact a texting and driving ban. Can the laws banning texting while driving actually work? The answer is probably not. The new Pennsylvania law which prohibits text-based communication is as follows: 


\title{
Issues in Information Systems \\ Volume 13, Issue 1, pp. 275-283, 2012
}

\begin{abstract}
No driver shall operate a motor vehicle on a highway or trafficway in the Commonwealth while using an interactive wireless communications device to send, read or write a text-based communication while the vehicle is in motion. A person does not send, read or write a textbased communication when the person reads, selects or enters a telephone number or name in an interactive wireless communications device for the purpose of activating or deactivating a voice communication or a telephone call [14].
\end{abstract}

Texting while driving is a summary offense that carries a $\$ 50$ fine, court costs, and fees, but no points. The offense is not recorded on the driver's record. However, it is recorded for those with a commercial driver's license as a nonsanctioned violation. In 2010, according to the Pennsylvania Department of Transportation [13], there were 13,846 crashes that were attributed to distracted driving. Of those, there were 1,093 crashes and 11 fatalities in which at least one driver used a handheld phone [13].

The texting law does not apply to a person using the phone to read or dial a phone number, and it also does not apply to a person using the phone to text while the vehicle is not in motion. For example, if an officer pulls a person over for texting, the driver could actually say that they were dialing a 10-digit number. How can an officer prove, without wasting time and money to subpoena the service provider's records, that the driver was actually texting? It is almost impossible.

\section{CONCLUSIONS}

Distracted driving, and in particular texting while driving, is gaining national attention. Public awareness campaigns such as the New Ad Council's "Stop the Texts, Stop the Wrecks," and Volkswagen/Audi's employee pledge, "Enjoy the Ride, Don't Text and Drive" are gaining national recognition. Displayed on billboards throughout Pennsylvania one will see "dnt txt $\mathrm{n}$ drv." Laws in all 50 states have been enacted in regard to drinking while driving. Drinking while driving still exists, but imagine for a moment how bad things might be if the strict laws and penalties were not enforced. In order for texting bans to be effective, tougher penalties and fines must be attached to the laws. Training and education is key to solving the problem of texting while driving. Once the extent of the problem is understood, only then can effective changes in regard to texting while driving take place.

\section{REFERENCES}

1. AAA Foundation for Traffic Safety. (n.d.). Distracted driving. Retrieved April 24, 2012, from http://www.aaafoundation.org/multimedia/distracteddriving.cfm

2. Braitman, K. \& McCartt, A. (2010). National reported patterns of driver cell phone use in the United States. Traffic Injury Prevention, 11(6), 543-548.

3. CTIA The Wireless Association. (2011). Wireless quick facts: year-end figures. Retrieved April 24, 2012, from http://www.ctia.org/media/industry_info/index.cfm/AID/10323

4. Exec. Order No. 13,513, C.F.R. 192 (2009 comp). Federal leadership on reducing text messaging while driving.

5. Governors Highway Safety Association: The States' Voice on Highway Safety. (2012, May). Cell phone and texting laws. Retrieved April 23, 2012, from: http://www.ghsa.org/html/stateinfo/laws/cellphone_laws.html

6. Harris Interactive. (2011). Most drivers with cell phones use them while driving even though they know it is unsafe; more than one in five text while driving. Retrieved on March 21, 2012, from: http://www.harrisinteractive.com/NewsRoom/HarrisPolls/tabid/447/mid/1508/articleId/836/ct1/ReadCustom\%2 ODefault/Default.aspx

7. Just, M., Keller, T., Cynkar, J. (2008). A decrease in brain activation associated with driving when listening to someone speak. Center for Cognitive Brain Imaging, Department of Psychology, Carnegie Mellon University. Brain research. Elsevier, 1205, 70-80.

8. Madden, M. \& Rainie, L. (2010). Adults and cell phone distractions. Pew Internet \& American Life Project. Retrieved April 10, 2012, from http://pewinternet.org/Reports/2010/Cell-Phone-Distrations.aspx 


\section{Issues in Information Systems}

Volume 13, Issue 1, pp. 275-283, 2012

9. National Safety Council. (n.d.). Distracted driving research and statistics. Retrieved April 23, 2012, from http://www.nsc.org/safety_road/Distracted_Driving/Pages/DistractedDrivingResearchandStatistics.aspx

10. NHTSA Traffic Tech: Technology Transfer Series, Number 407. (2011). National distracted driving telephone survey finds most drivers answer the call, hold the phone, and continue to drive. Retrieved April 23, 2012, from: http://www.distraction.gov/download/research-pdf/8397_TSFTT_DistractedDrivingSurvey_120711_v4_tag.pdf

11. NHSTA U.S. Department of Transportation. (2012). What is distracted driving? Key facts and statistics. Retrieved on April 10, 2012, from: http://www.distraction.gov/content/get-the-facts/facts-and-statistics.html

12. Paullet, K. L., Pinchot, J. L., \& Rota, D. R. (2010). Technology: Convenience or necessity. Issues in Information Systems, XI(1), pp. 439-444.

13. Pennsylvania Department of Transportation. (n.d.). Anti-texting law facts. Retrieved April 26, 2012, from ftp://ftp.dot.state.pa.us/public/Bureaus/Press/Texting_Ban_Fact_Sheet.pdf

14. Pennsylvania Vehicles Code. (2012, March). Prohibiting text-based communications. PA STAT Sec 3316 Title 7 Vehicles. 